\title{
Vitamin D supplementation reduces insulin resistance in South Asian women living in New Zealand who are insulin resistant and vitamin D deficient - a randomised, placebo-controlled trial
}

\author{
Pamela R. von Hurst ${ }^{1}$, Welma Stonehouse ${ }^{1}$ and Jane Coad $^{2}$ \\ ${ }^{1}$ Institute of Food, Nutrition and Human Health, Massey University, Private Bag 102 904, North Shore Mail Centre, \\ Auckland, New Zealand \\ ${ }^{2}$ Institute of Food, Nutrition and Human Health, Massey University, Palmerston North, New Zealand \\ (Received 4 June 2009 - Revised 6 August 2009 - Accepted 11 August 2009 - First published online 28 September 2009)
}

Low serum 25-hydroxyvitamin D (25(OH)D) has been shown to correlate with increased risk of type 2 diabetes. Small, observational studies suggest an action for vitamin D in improving insulin sensitivity and/or insulin secretion. The objective of the present study was to investigate the effect of improved vitamin D status on insulin resistance (IR), utilising randomised, controlled, double-blind intervention administering $100 \mu \mathrm{g}$ (4000 IU) vitamin $\mathrm{D}_{3}(n$ 42) or placebo ( $n$ 39) daily for 6 months to South Asian women, aged 23-68 years, living in Auckland, New Zealand. Subjects were insulin resistant - homeostasis model assessment 1 (HOMA1) $>1.93$ and had serum $25(\mathrm{OH}) \mathrm{D}$ concentration $<50 \mathrm{nmol} / \mathrm{l}$. Exclusion criteria included diabetes medication and vitamin D supplementation $>25 \mu \mathrm{g}(1000 \mathrm{IU}) / \mathrm{d}$. The HOMA2 computer model was used to calculate outcomes. Median (25th, 75th percentiles) serum $25(\mathrm{OH}) \mathrm{D}_{3}$ increased significantly from $21(11,40)$ to $75(55,84) \mathrm{nmol} / \mathrm{l}$ with supplementation. Significant improvements were seen in insulin sensitivity and IR $(P=0.003$ and 0.02 , respectively), and fasting insulin decreased $(P=0.02)$ with supplementation compared with placebo. There was no change in C-peptide with supplementation. IR was most improved when endpoint serum $25(\mathrm{OH}) \mathrm{D}$ reached $\geq 80 \mathrm{nmol} / \mathrm{l}$. Secondary outcome variables (lipid profile and high sensitivity C-reactive protein) were not affected by supplementation. In conclusion, improving vitamin D status in insulin resistant women resulted in improved IR and sensitivity, but no change in insulin secretion. Optimal vitamin D concentrations for reducing IR were shown to be $80-119$ nmol/1, providing further evidence for an increase in the recommended adequate levels. Registered Trial No. ACTRN12607000642482.

Vitamin D: Type 2 diabetes: Insulin resistance

There is mounting interest in the role of vitamin $\mathrm{D}$ in the aetiology of type 2 diabetes, and the most commonly preceding conditions, reduced insulin sensitivity and compromised $\beta$-cell function.

Low serum 25-hydroxyvitamin D $(25(\mathrm{OH}) \mathrm{D})$ concentrations have been shown to correlate with impaired glucose tolerance and an increased risk of type 2 diabetes ${ }^{(1-5)}$, while a correlation between hypovitaminosis D and insulin resistance (IR) has been identified in pregnant women and obese adolescents ${ }^{(6,7)}$. A 10-year prospective study identified an inverse relationship between baseline serum $25(\mathrm{OH}) \mathrm{D}$ concentrations and later risk of $\mathrm{IR}^{(8)}$. Administration of supplemental vitamin $\mathrm{D}$ to subjects with elevated blood glucose levels has resulted in an improvement in insulin secretion ${ }^{(9,10)}$, and similar improvements have been observed in vitamin D-deficient subjects following supplementation ${ }^{(1,11)}$.

Tai et al. ${ }^{(12)}$ found no improvement in glucose tolerance following the administration of two vitamin $\mathrm{D}$ doses $(2500 \mu \mathrm{g} ; 100000 \mathrm{IU})$ with an interval of 2 weeks to thirty-seven non-diabetic, vitamin D-deficient adults. Nagpal et al. ${ }^{(13)}$ reported a randomised, controlled trial of vitamin $\mathrm{D}_{3}$, three fortnightly doses of $3000 \mu \mathrm{g}$ (120000 IU) or placebo, in centrally obese Indian men. The subjects were not necessarily insulin resistant, but there was some improvement in postprandial insulin sensitivity following supplementation. A recent systematic review and meta-analysis on the role of vitamin $\mathrm{D}$ and calcium in type 2 diabetes conclude that 'there appears to be a relationship' but due to the paucity of data, an understanding of the mechanisms is incomplete ${ }^{(14)}$.

To date, there have been no randomised, controlled trials with vitamin $\mathrm{D}$ supplementation of a dose sufficient to raise serum $25(\mathrm{OH}) \mathrm{D}$ to $>80 \mathrm{nmol} / \mathrm{l}$ in vitamin D-deficient, nondiabetic, insulin-resistant subjects. It has been shown that a dose of vitamin $\mathrm{D}>50 \mu \mathrm{g}$ (2000 IU) per day is required to raise and maintain serum concentration to $80 \mathrm{nmol} / \mathrm{l}^{(15)}$. However, the increase in serum levels is related to baseline concentration, and where a patient is severely deficient $(<12.5 \mathrm{nmol} / \mathrm{l})$, a higher dose may be required ${ }^{(16)}$. Earlier

Abbreviations: FSG, fasting serum glucose; HOMA, homeostasis model assessment; IR, insulin resistance; MMP, matrix metalloproteinases; 25(OH)D, 25-hydroxyvitamin D.

* Corresponding author: Pamela R. von Hurst, fax +649443 9640, email p.r.vonhurst@massey.ac.nz 
concerns about the toxic effects of high doses of supplemental vitamin $\mathrm{D}$ have been allayed by safety and efficacy tests, which have demonstrated that doses of 100 and $250 \mu \mathrm{g}$ (4000 and $10000 \mathrm{IU})$ per day for 5-6 months resulted in no toxic effects $^{(16,17)}$.

The population of interest in the present study is women of South Asian origin living in Auckland, New Zealand. There is a threefold higher prevalence of self-reported diabetes in South Asians living in New Zealand compared with the general population $^{(18)}$, and we have previously reported a prevalence of hypovitaminosis D of $84 \%$ in South Asian women ${ }^{(19)}$.

\section{Aim}

The aim was to investigate the effect of improved vitamin D status on markers of metabolic syndrome, primarily IR, in South Asian women who were insulin resistant and vitamin $\mathrm{D}$ deficient.

\section{Method}

The study protocol is described in greater detail elsewhere ${ }^{(20)}$. In brief, the study design was a randomised, placebocontrolled, double-blind trial with $100 \mu \mathrm{g}$ (4000 IU) vitamin $\mathrm{D}_{3}$ (cholecalciferol) per day (four capsules of $25 \mu \mathrm{g}$ (1000 IU) each) or four capsules of placebo per day for 6 months. Women of South Asian origin ( $n$ 235) were recruited and screened for hypovitaminosis $\mathrm{D}$ (serum $25(\mathrm{OH}) \mathrm{D}<50$ nmol/l) plus IR (homeostasis model assessment, HOMAIR $\geq 1.93$ ) and/or TAG/HDL cholesterol ratio $\geq 3.0$. There are no recognised HOMA-IR cut-offs for this population, and the rather arbitrary selection of 1.93 was based on the findings of the Chennai Urban Population Study in India where the upper quartile was found to have a HOMA-IR score $\geq 1.93^{(21)}$. An elevated TAG/HDL ratio has been identified as a strong predictor of IR and metabolic syndrome ${ }^{(22)}$. Exclusion criteria included fasting serum glucose (FSG) $\geq 7.2 \mathrm{mmol} / \mathrm{l}$, medication for diabetes and vitamin D supplementation $\geq 25 \mu \mathrm{g}$ (1000 IU) per day.

Subjects were matched into pairs by age and BMI. Randomisation of the vitamin D/placebo capsules and allocation to the members of each pair were performed by Blackmores Ltd using nQuery Advisor ${ }^{\circledR}$, version 6.0 (Statistical Solutions, Cork, Ireland). Randomisation and allocation were fully concealed from the researchers until after statistical analysis of the data.

Fasting blood samples and anthropometric measurements were obtained at baseline and the end of the study. The intervention in the original cohort commenced in July 2007, which is mid-winter in New Zealand, and a second small cohort ( $n$ 7) commenced in October 2007 following the early loss of subjects from the study (see Results section). Subjects were recalled for their final blood test 6 months later i.e. January 2008 (mid-summer) and April 2008. Subjects were also recalled for a blood test at 3 months. This was primarily to check for adverse effects in response to the high dose of vitamin D supplementation. Serum Ca results were immediately checked for abnormality by a colleague not associated with the study, and results were entered into the database at the end of the study. Subjects were advised to contact research staff immediately if they suspected a reaction to the supplements.
The original HOMA1 model for IR was used for subject selection as explained above ${ }^{(23)}$. This model utilises a simple linear equation based on pairing FSG and fasting serum insulin to establish a measure for IR: HOMA1-IR = (fasting serum insulin $\times$ FSG)/22.5. The technique is simple and inexpensive with relatively low subject burden, and has been shown to correlate well with the glucose clamp in predicting insulin sensitivity ${ }^{(24,25)}$.

The revised HOMA2 model was utilised to assess outcomes of the intervention. This is a computer model consisting of non-linear empirical equations that, when solved, allow the determination of insulin sensitivity (HOMA2\%S) from FSG and fasting serum insulin, and $\beta$-cell function (HOMA2 \%B) from paired FSG and C-peptide. C-peptide is a reliable marker for insulin secretion as, unlike insulin, it is not taken up by the liver ${ }^{(25)}$. Both $\beta$-cell function and insulin sensitivity are reported as a percentage, where $100 \%$ is normal ${ }^{(26)}$. IR is the reciprocal of percentage sensitivity, and 1.0 is normal.

Methods for all measurements and laboratory analysis of FSG, fasting serum insulin, lipid profile, high sensitivity C-reactive protein, $\mathrm{Ca}$ and serum $25(\mathrm{OH}) \mathrm{D}$ are reported in von Hurst et al. ${ }^{(20)}$. C-peptide was measured in EDTA plasma samples stored at $-80^{\circ} \mathrm{C}$, by Canterbury District Health Board Laboratory (Christchurch, New Zealand), performed on the automated Roche Elecsys 2010 analyser, CV (within batch) of $2.4 \%$ at $620 \mathrm{pmol} / \mathrm{l}$. Insulin and glucose were measured by LabPlus (Auckland, New Zeland). Insulin method: microparticle enzyme immunoassay technology (Abbott Diagnostics, Abbott Park, IL, USA); intra-assay CV $4.0 \%$ at $57.6 \mathrm{pmol} / 1$ (8.3 mU/l); inter-assay CV $4.5 \%$ at $58.3 \mathrm{pmol} / \mathrm{l}(8.4 \mathrm{mU} / \mathrm{l})$. Glucose method: standard enzymatic colourimetric assay (Roche Diagnostics, Basel, Switzerland); intra-assay CV $0.8 \%$ at $6.6 \mathrm{mmol} / \mathrm{l}$; inter-assay $\mathrm{CV} 1.8 \%$ at $6.6 \mathrm{mmol} / 1$.

\section{Statistical methods}

It was calculated that forty-two subjects would be required for each arm of the trial to demonstrate a significant difference at $80 \%$ power and $5 \%$ significance. Power calculations were based on the results of a lifestyle intervention in obese women, which achieved a reduction in HOMA-IR of 0.98 $(\text { SD } 0.77)^{(27)}$. Serum $25(\mathrm{OH}) \mathrm{D}$, high sensitivity C-reactive protein, insulin, glucose, plasma C-peptide and HOMA1 and 2 were not normally distributed and are reported as median (25th, 75th percentiles). Normally, distributed data are reported as means and standard deviations. Non-parametric tests were used to compare groups (Mann-Whitney $U$ test), and to compare baseline and endpoint measures within groups (Wilcoxon). The Kruskal-Wallis test and post hoc tests plus Bonferroni adjustments were used to compare more than two independent groups or conditions, and the Friedman's ANOVA and post hoc tests plus adjustments to compare more than two related groups. A two-tailed $P$-value of $<0.05$ was considered statistically significant. Pearson's correlations were used for normally distributed data, and Spearman's correlations used for non-parametric data.

\section{Ethical approval}

The present study was conducted according to the guidelines laid down in the Declaration of Helsinki, and all procedures 
involving human subjects were approved by the Massey University Human Ethics Board (Southern A), Reference no. 06/67. Written informed consent was obtained from all subjects.

\section{Results}

Two hundred and thirty-five women were recruited and screened for IR and hypovitaminosis D. One hundred and fourteen qualified for selection, and from those 106 women volunteered to take part in the intervention trial. Twelve were lost to the study due to becoming pregnant (n 3), moving overseas $(n 4)$, perceived side effects (headaches and constipation; $n 2$ ) and medical practitioner prescribing vitamin $\mathrm{D}$ ( $n$ 3). Following the early loss of the above-mentioned subjects, the study was reopened for recruitment to ensure sufficient numbers. Seven women joined the RCT 4 months after the initial cohort - their numbers are included in the totals above. A further thirteen women could not be contacted/traced at the end of the trial. The baseline characteristics of this group of twenty-five women (eleven from the vitamin D group and fourteen from the placebo group) did not differ significantly from those participants who remained in the study.

The majority of participants $(91 \%)$ were Indian, with $6 \%$ from Sri Lanka and 3\% from Pakistan. Of the participants, $79 \%$ had been in New Zealand for $\leq 10$ years, and no relationship was seen between time in New Zealand and baseline 25(OH)D.

Baseline characteristics of the vitamin D and placebo groups are shown in Table 1. There were no significant differences between the groups at baseline in any of the measures reported. BMI did not change significantly in either group during the study. While there was no relationship between HOMA-IR and age, a positive correlation was seen between HOMA-IR and BMI at baseline ( $r$ 0.316, $P=0.004)$. No adverse effects were observed in the serum calcium results at 3 months.
Serum 25(OH)D concentrations increased significantly in the vitamin D-supplemented group, from $21(11,40) \mathrm{nmol} / \mathrm{l}$ at baseline to $93(69,103) \mathrm{nmol} / \mathrm{l}$ at 3 months and then declined to $80(67,94) \mathrm{nmol} / \mathrm{l}$ at 6 months. There was also a significant increase in the placebo group between 3 months at $21(15,36) \mathrm{nmol} / \mathrm{l}$ and 6 months at $29(23,46) \mathrm{nmol} / \mathrm{l}$ $(P=0 \cdot 014)$. A significant inverse relationship was found between baseline concentrations of $25(\mathrm{OH}) \mathrm{D}$ and the change in serum $25(\mathrm{OH}) \mathrm{D}$ over 6 months in both the vitamin $\mathrm{D}$ $(r-0.349, P=0.023)$ and placebo $(r-0.456, P=0.004)$ groups. There was no relationship between change in vitamin D concentration and BMI.

Significant improvements were seen in insulin sensitivity, IR and fasting insulin (Table 2), with supplementation compared with placebo. There was a significant difference in the change in HOMA1-IR between groups $(P=0.03)$, with a decrease of $-0.25(0.24,-0.81)$ in the vitamin D-supplemented group and an increase of $0.36(1.16,-0.41)$ in the placebo group. Changes in FSG, HOMA2\%B, $\mathrm{C}$-peptide, high sensitivity $\mathrm{C}$-reactive protein, total cholesterol, TAG/HDL cholesterol ratio, HDL cholesterol and TAG were NS within, and did not differ between, groups. In the vitamin D-supplemented group, HOMA2 \%S increased $(P=0.01)$, fasting insulin declined $(P=0.02)$ and overall IR decreased compared with baseline $(P=0 \cdot 03)$. To eliminate regression toward the mean as a confounder, change was calculated by subtracting endpoint values from the mean of baseline and endpoint HOMA2 $\% \mathrm{~S}$; the difference between groups remained significant $(P=0 \cdot 003)$.

Sixteen out of the forty-two women in the vitamin D group achieved serum $25(\mathrm{OH}) \mathrm{D}$ concentrations of $>80 \mathrm{nmol} / \mathrm{l}$ at both the 3 and 6 month tests. In these women, HOMA $2 \% \mathrm{~S}$ increased from $60 \cdot 1(50.9,70.5)$ at baseline to $66.4(55 \cdot 3,84.5)$ at 3 months $(P=0 \cdot 12)$, but the increase did not achieve significance until 6 months when HOMA2 $\% \mathrm{~S}$ reached 85.8 (47.3, 103.9; $P=0 \cdot 013$; Fig. 1).

Table 1. Baseline characteristics of trial participants

(Mean values and standard deviations*; median values and 25th, 75th percentilest)

\begin{tabular}{|c|c|c|c|c|}
\hline & \multicolumn{2}{|c|}{ Vitamin D group ( $n$ 42) } & \multicolumn{2}{|c|}{ Placebo group ( $n 39)$} \\
\hline & Mean & SD & Mean & SD \\
\hline Age (years) & $41 \cdot 8$ & $10 \cdot 1$ & 41.5 & $9 \cdot 1$ \\
\hline $\mathrm{BMI}\left(\mathrm{kg} / \mathrm{m}^{2}\right)$ & 27.5 & $5 \cdot 0$ & $27 \cdot 4$ & 3.7 \\
\hline Waist-hip ratio & 0.80 & 0.07 & 0.80 & 0.06 \\
\hline Systolic blood pressure (mmHg) & $121 \cdot 6$ & $17 \cdot 6$ & $124 \cdot 0$ & $15 \cdot 7$ \\
\hline \multirow{2}{*}{ Diastolic blood pressure $(\mathrm{mmHg})$} & 80.4 & 8.9 & 80.9 & 9.9 \\
\hline & Median & 25th, 75th percentiles & Median & 25th, 75 th percentiles \\
\hline HOMA-IR (HOMA1 model) & $2 \cdot 70$ & $2 \cdot 13,3 \cdot 61$ & 2.53 & $2 \cdot 11,3.47$ \\
\hline Total cholesterol (mmol/l) & $5 \cdot 1$ & $4.5,5.5$ & 4.7 & $4 \cdot 3,5 \cdot 5$ \\
\hline LDL-C (mmol/l) & $3 \cdot 2$ & $2.9,3.5$ & $3 \cdot 0$ & $2 \cdot 5,3 \cdot 3$ \\
\hline $\mathrm{HDL}-\mathrm{C}(\mathrm{mmol} / \mathrm{l})$ & 1.2 & $1 \cdot 0,1 \cdot 4$ & 1.2 & $1 \cdot 0,1.4$ \\
\hline TAG $(\mathrm{mmol} / \mathrm{l})$ & 1.4 & $0.9,1.7$ & $1 \cdot 1$ & $0.7,1.6$ \\
\hline TAG/HDL-C ratio & $2 \cdot 6$ & $1.9,3.6$ & $2 \cdot 0$ & $1.4,3.3$ \\
\hline
\end{tabular}

HOMA-IR, homeostasis model assessment insulin resistance; LDL-C, LDL cholesterol; HDL-C, HDL cholesterol.

There were no significant differences between the groups in any of the variables reported above (for statistics between groups: non-parametric variables - Mann-Whitney $U$ test; parametric variables - independent $t$ test). Baseline $25(\mathrm{OH}) \mathrm{D}$, fasting serum glucose (FSG), fasting serum insulin (FSI) and high sensitivity C-reactive protein (hs-CRP) are reported in Table 2.

* Data are normally distributed.

†Data are not normally distributed. 
Table 2. Changes from baseline to endpoint measures of primary outcomes within vitamin $D$ and placebo groups, and between groups (Median values and 25th, 75th percentiles)

\begin{tabular}{|c|c|c|c|c|c|c|c|}
\hline & \multicolumn{3}{|c|}{ Vitamin D ( $n$ 42) } & \multicolumn{3}{|c|}{ Placebo (n 39) } & \multirow[b]{2}{*}{$\begin{array}{c}P \text { value (difference } \\
\text { between groups) }\end{array}$} \\
\hline & Median & $\begin{array}{l}\text { 25th, } 75 \text { th } \\
\text { percentiles }\end{array}$ & $\begin{array}{l}P \text { value difference } \\
\text { within group }\end{array}$ & Median & $\begin{array}{l}\text { 25th, } 75 \text { th } \\
\text { percentiles }\end{array}$ & $\begin{array}{l}P \text { value difference } \\
\text { within group }\end{array}$ & \\
\hline \multicolumn{8}{|l|}{$25(\mathrm{OH}) \mathrm{D}(\mathrm{nmol} / \mathrm{l})$} \\
\hline Baseline & 21 & 11,40 & $<0.001$ & 19 & 13,29 & $<0.001$ & \\
\hline End & 80 & 67,94 & & 29 & 23,36 & & \\
\hline Change: end - baseline & 49 & 21,66 & & 8 & $-1,16$ & & $<0.001$ \\
\hline \multicolumn{8}{|l|}{ HOMA2\%S } \\
\hline Baseline & $60 \cdot 6$ & $46 \cdot 7,77 \cdot 7$ & 0.01 & $65 \cdot 9$ & $50 \cdot 7,74.5$ & 0.69 & \\
\hline End & $68 \cdot 0$ & $52 \cdot 6,102 \cdot 1$ & & 60.4 & $44.8,74.0$ & & \\
\hline Change: end - baseline & 5.9 & $-4 \cdot 1,29 \cdot 8$ & & -5.9 & $-25 \cdot 0,13.5$ & & 0.003 \\
\hline \multicolumn{8}{|l|}{ HOMA2\%B } \\
\hline Baseline & 163 & 129,181 & 0.17 & 144 & 120,182 & 0.39 & \\
\hline End & 152 & 126,180 & & 149 & 122,181 & & \\
\hline Change: end - baseline & $-11 \cdot 2$ & $18 \cdot 0,-24.5$ & & 0.6 & $-25 \cdot 0,12 \cdot 5$ & & 0.09 \\
\hline \multicolumn{8}{|l|}{ HOMA2-IR } \\
\hline Baseline & $1 \cdot 7$ & $1 \cdot 3,2 \cdot 1$ & 0.03 & 1.5 & $1 \cdot 3,2 \cdot 0$ & 0.27 & \\
\hline End & 1.5 & $1.0,1.9$ & & 1.7 & $1 \cdot 4,2 \cdot 2$ & & \\
\hline Change: end - baseline & -0.2 & $-0.4,0.1$ & & 0.2 & $-0.3,0.6$ & & 0.02 \\
\hline \multicolumn{8}{|l|}{$\mathrm{FSI}(\mathrm{mU} / \mathrm{l})^{\star}$} \\
\hline Baseline & $13 \cdot 2$ & $10 \cdot 1,16 \cdot 8$ & 0.02 & 11.9 & $9 \cdot 9,15 \cdot 4$ & 0.27 & \\
\hline End & 11.2 & $7.9,11.9$ & & $13 \cdot 1$ & $10 \cdot 2,17 \cdot 3$ & & \\
\hline Change: end - baseline & -1.3 & $-3 \cdot 6,1 \cdot 0$ & & 1.1 & $-2 \cdot 5,4 \cdot 2$ & & 0.02 \\
\hline \multicolumn{8}{|l|}{$\mathrm{FSG}(\mathrm{mmol} / \mathrm{l})$} \\
\hline Baseline & 4.7 & $4 \cdot 5,5 \cdot 1$ & 0.154 & 4.9 & $4 \cdot 5,5 \cdot 2$ & 0.07 & \\
\hline End & $4 \cdot 8$ & $4 \cdot 6,5 \cdot 2$ & & $5 \cdot 0$ & $4 \cdot 7,5 \cdot 4$ & & \\
\hline Change: end - baseline & 0.1 & $0.4,-0.1$ & & 0.1 & $0.4,-0.2$ & & 0.82 \\
\hline $\begin{array}{l}\text { ns-Chr (mg/l) } \\
\text { Baseline }\end{array}$ & 2.5 & $1 \cdot 0,4 \cdot 5$ & 0.19 & $2 \cdot 4$ & $1 \cdot 0,4 \cdot 6$ & 0.38 & \\
\hline End & $2 \cdot 15$ & $1.25,3.4$ & & 2.9 & $1 \cdot 5,4 \cdot 6$ & & \\
\hline Change: end - baseline & 0.00 & $-1.05,0.4$ & & 0.2 & $-0.1,0.7$ & & 0.05 \\
\hline \multicolumn{8}{|l|}{ C-peptide $(\mathrm{nmol} / \mathrm{l})$} \\
\hline Baseline & 0.81 & $0.67,1 \cdot 1$ & 0.97 & 0.83 & $0.64,0.94$ & 0.11 & \\
\hline End & 0.81 & $0.68,1.0$ & & $0 \cdot 86$ & $0.69,0.95$ & & \\
\hline Change: end - baseline & -0.002 & $-0.09,0.07$ & & 0.07 & $-0.1,0.21$ & & 0.15 \\
\hline
\end{tabular}

25(OH)D, 25-hydroxyvitamin D; HOMA2\%S, homeostasis model assessment computer model - percentage sensitivity; HOMA2\%B, HOMA2 - percentage 3 -cell function; HOMA2-IR, HOMA2 insulin resistance; FSI, fasting serum insulin; FSG, fasting serum glucose; hs-CRP, high sensitivity C-reactive protein. Columns 3 and 5 are the significance $(P$ value) for the change within each group from baseline to endpoint. Column 6 is the significance of the difference between groups in the change for each variable. Non-parametric tests were used to compare groups (Mann-Whitney $U$ test), and to compare baseline and endpoint measures within groups (Wilcoxon).

$* 1 \mathrm{mU} / \mathrm{l}=6.94 \mathrm{pmol} / \mathrm{l}$.

\section{Discussion}

The present study demonstrates that supplementation with vitamin $\mathrm{D}$ in women who are both vitamin $\mathrm{D}$ deficient and insulin resistant can enhance insulin sensitivity if the dose is large enough and continued over a sufficient length of time. Recent studies investigating the effect of high dose (2500 and $3000 \mu \mathrm{g}$ (100000 and $120000 \mathrm{IU})$ per fortnight) vitamin D supplementation on glucose homeostasis have reported inconclusive results ${ }^{(12,13)}$, but have supplemented over a shorter time period (4 or 6 weeks), and subjects have not necessarily been insulin resistant. The women participating in the present study had elevated HOMA-IR, the intervention was for 6 months, and although there was a trend towards improvement in insulin sensitivity (HOMA2\%S), after 3 months, no significant change was seen until 6 months (Fig. 1).

The wide range of endpoint serum $25(\mathrm{OH}) \mathrm{D}$ concentrations in the vitamin D group $(10-119 \mathrm{nmol} / \mathrm{l})$ suggests variable compliance. Subjects reported finding it difficult to consistently consume four capsules per day for 6 months. The decline in median serum levels from the 3-month tests to endpoint in the vitamin D group probably reflects compliance dropping off in the latter half of the study. Meanwhile, it is likely that the increase in serum $25(\mathrm{OH}) \mathrm{D}$ concentrations in the placebo group from mid-study is due to more incidental sun exposure and higher levels of UVB with the approach of summer, to which the supplement group would also have been exposed. We have previously reported a small increase in the $25(\mathrm{OH}) \mathrm{D}$ concentrations in South Asian women who were tested during late summer, compared with those tested during winter and spring ${ }^{(19)}$.

The method of administration of the supplement in the present study (daily dose) differed from the large fortnightly doses used in recent studies ${ }^{(12,13)}$ and the approved prescription dose in New Zealand of $1250 \mu \mathrm{g}$ (50000 IU) per month ${ }^{(28)}$. While the larger, less frequent doses may be advantageous from a compliance perspective, daily doses have been shown to be more effective than weekly or monthly doses as measured by serum $25(\mathrm{OH}) \mathrm{D}$, parathyroid hormone and bone markers ${ }^{(29)}$. It is possible that a single, large bolus could have negative outcomes; Taylor \& $\mathrm{Wise}^{(30)}$ treated three vitamin D-deficient individuals with type 2 diabetes with one intramuscular dose of $7500 \mu \mathrm{g}(300000 \mathrm{IU})$ of vitamin $\mathrm{D}_{2}$ and saw an increase in hyperglycaemia and lipidaemia ${ }^{(30)}$. 


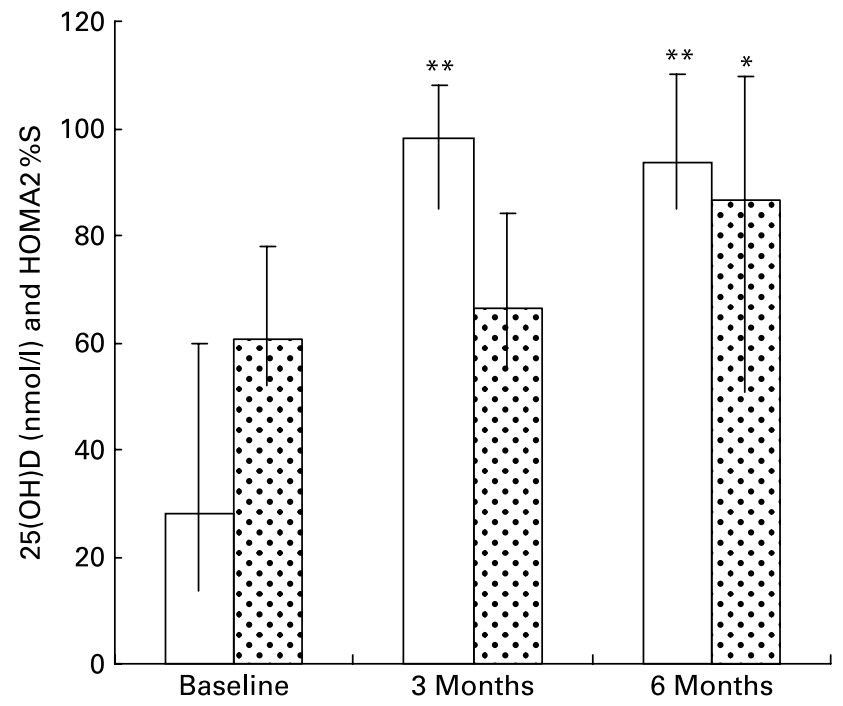

Fig. 1. Changes in serum 25-hydroxyvitamin D (25(OH)D) ( $\square$ ) and HOMA2\%S (淄) over time in subjects $(n$ 16) whose endpoint serum $25(\mathrm{OH}) \mathrm{D}$ was $>80 \mathrm{nmol} / \mathrm{l}$. Mean value was significantly different from that at baseline: ${ }^{*} P=0.013,{ }^{*} P<0.001$. $Y$-axis values include both serum $25(\mathrm{OH}) \mathrm{D}(\mathrm{mmol} / \mathrm{l})$ and HOMA2 $\%$ S where $100 \%$ is ideal. The Friedman's ANOVA and post hoc tests with adjustments were used to compare more than two related groups.

The significant inverse relationship between baseline concentration and increase in serum $25(\mathrm{OH}) \mathrm{D}$ suggests that baseline values influence the response to both cutaneous synthesis and supplementation. This is in agreement with other evidence that low baseline levels produce a steep dose-response slope in response to supplementation ${ }^{(16,29,31)}$, and is possibly due to feedback regulation, although synthesis of $25(\mathrm{OH}) \mathrm{D}$ in the liver is only loosely regulated ${ }^{(32)}$.

Previous vitamin D supplementation studies, especially those in diabetic subjects, have concentrated on the role of vitamin $\mathrm{D}$ in increased insulin secretion ${ }^{(10)}$. There is also considerable evidence from animal studies that adequate $25(\mathrm{OH}) \mathrm{D}$ concentrations are required for normal insulin secretion $^{(33-35)}$.

Subjects in the present study were not diabetic, insulin secretion was not compromised and there was no change in C-peptide levels, suggesting that insulin secretion did not increase in response to supplementation. With the increase in serum $25(\mathrm{OH}) \mathrm{D}$ concentration in the vitamin D group, IR improved, driven by an upward shift in insulin sensitivity and a corresponding drop in fasting insulin as tissue extraction of insulin increased. Insulin sensitivity was significantly improved when the endpoint serum $25(\mathrm{OH}) \mathrm{D}$ concentrations exceeded $80 \mathrm{nmol} / \mathrm{l}$. These findings support those of Chiu et al. ${ }^{(36)}$ in a cross-sectional study, which suggested enhanced insulin sensitivity might be seen if $25(\mathrm{OH}) \mathrm{D}$ concentration was to be increased from 25 to $75 \mathrm{nmol} / \mathrm{l}$. The same study also reported a subtle variation in $\beta$-cell response to an oral glucose tolerance test at different vitamin D concentrations ${ }^{(36)}$.

There have been at least two mechanisms postulated for an increase in insulin sensitivity in response to improved vitamin D status - suppression of chronic inflammation and increased expression of the insulin receptor and/or proteins of the insulin-signalling cascade. A mild inflammatory state, marked by the presence of proinflammatory cytokines, is associated with obesity and IR. These cytokines, predominantly TNF- $\alpha$ and IL-6, are known to be released from adipose tissue ${ }^{(37)}$, and increased serum concentrations are known to induce IR in multiple tissues ${ }^{(38)}$. Vitamin $\mathrm{D}$ has recognised antiinflammatory actions: it has been shown to dose dependently suppress the release of TNF- $\alpha$ and IL- $6^{(39,40)}$ while up-regulating synthesis of the anti-inflammatory cytokine IL- $10^{(39,41)}$, thus potentially partly counteracting the inflammatory consequences of increased adiposity. Plasma matrix metalloproteinases (MMP) are also inflammatory markers and are associated with vascular damage and unstable angina. MMP2 and MMP9 have been shown to be inversely correlated with vitamin D status, and reduced with vitamin D supplementation ${ }^{(42)}$.

CRP is considered to be a useful biomarker for the presence of TNF- $\alpha$ and IL-6. In the present study, we measured only high sensitivity C-reactive protein; baseline levels were within the normal range in each group and the reduction following supplementation was NS. Participants, although overweight, were not obese and mean waist/hip ratio did not exceed $0 \cdot 80$. These characteristics are similar to those found in women of other ethnicities, and in centrally obese Indian men ${ }^{(13,43)}$. It is conceivable that the inflammatory effects of increased adiposity were not a major cause of their IR; thus, the anti-inflammatory action of vitamin D is unlikely to explain the improved IR observed in the present study. Future studies, especially in subjects susceptible to inflammation, should measure IL-6, TNF- $\alpha$, IL-10 and possibly MMP2 and MMP9 to further explore this as a plausible mechanism.

A second potential mechanism for the influence of vitamin $\mathrm{D}$ on insulin sensitivity is in the regulation of the insulinsignalling cascade. A vitamin D response element has been identified on the human insulin receptor (IR) gene promoter ${ }^{(44)}$, and in vitro treatment with 1,25-dihydroxyvitamin $D_{3}$ resulted in increased transcription of the insulin receptor gene, together with improved insulin-dependent glucose transport $^{(45,46)}$. Additionally, $1,25(\mathrm{OH})_{2} \mathrm{D}_{3}$ appears to stimulate glucose oxidation either via the activation of IR transcription or by a direct regulation of phosphatidylinositol 3-kinase activity $^{(46)}$. Murine studies have shown phosphatidylinositol 3-kinase and the insulin receptor substrate proteins to be important coordinators of insulin regulation ${ }^{(47)}$. Insulinstimulated activity of phosphatidylinositol 3-kinase and other proteins downstream of phosphatidylinositol 3-kinase such as protein kinase $\mathrm{C}$ has been shown to be impaired in obese and diabetic human subjects, and improved in obese subjects following weight loss ${ }^{(48)}$.

\section{Conclusions}

Insulin sensitivity did improve in these insulin-resistant women with vitamin D supplementation. No significant change was seen in insulin sensitivity until serum $25(\mathrm{OH}) \mathrm{D}$ concentrations reached levels above $80 \mathrm{nmol} / 1$, and despite substantial increase in serum $25(\mathrm{OH}) \mathrm{D}$ concentration at 3 months, there was no significant change in insulin sensitivity until 6 months. The findings provide further evidence for an increase in the recommended adequate levels of $25(\mathrm{OH}) \mathrm{D}$ from 50 to $80 \mathrm{nmol} / \mathrm{l}^{(15)}$, and suggest the importance of the long-term maintenance of adequate vitamin D levels. Differences in duration of studies could explain the disparity between the present results and those of Tai et al. ${ }^{(12)}$ and Nagpal et al. ${ }^{(13)}$. 
Future studies should examine the affect of vitamin D supplementation on both insulin secretion and sensitivity, as well as the potential anti-inflammatory effect of vitamin D, although this is possibly more relevant if the subjects are obese and inflammatory markers are elevated. Further investigation is required into the role of vitamin $\mathrm{D}$ in the expression of the insulin receptor gene and in the insulin-signalling pathway.

Interpersonal variations in sun exposure requirements, together with the accepted risks of excessive UV radiation, make it very difficult to give recommendations about sun exposure. Supplementation may be the best solution for some populations, especially those with darker skin living in temperate climates. However, as sufficiency of dose is critical, we need to learn more about the long-term safety and efficacy of high dose vitamin D supplements and the most effective way to deliver them.

\section{Acknowledgements}

The authors would like to thank the women of the Auckland South Asian community for their participation, encouragement and enthusiasm for the study. The authors also thank Dr R. Sood and staff of the Mount Roskill Medical Centre. Funding for the study was provided by the New Zealand Lottery Board (Lottery Health Grant) and New Zealand Department of Internal Affairs. Additional support was provided by Blackmores Pty Ltd, Australia, who supplied the vitamin D supplement and the placebo. P. R. v. H. is a recipient of the Massey University Doctoral Scholarship. The authors have no conflicts of interest to declare. Authors' contributions: P. v. R. H and J. C. designed the study, P. v. R. H. was study leader, W. S. designed lab protocols and advised on statistical analysis, all three authors participated in the writing of the present paper. We would also like to thank statistician, Dr Beatrix Jones for additional statistical advice.

\section{References}

1. Boucher B, Mannan N, Noonan K, et al. (1995) Glucose intolerance and impairment of insulin secretion in relation to vitamin D deficiency in East London Asians. Diabetologia 38, $1239-1245$.

2. Isaia G, Giorgino R \& Adami S (2001) High prevalence of hypovitaminosis D in female type 2 diabetic population. Diabetes Care 24, 1496.

3. Lucas JA, Bolland MJ, Grey AB, et al. (2005) Determinants of vitamin D status in older women living in a subtropical climate. Osteoporos Int 16, 1641-1648.

4. Scragg R, Holdaway I, Singh V, et al. (1995b) Serum 25-hydroxyvitamin $\mathrm{D}_{3}$ levels decreased in impaired glucose tolerance and diabetes mellitus. Diabetes Res Clin Pract 27, 181-188.

5. Mattila C, Knekt P, Mannisto S, et al. (2007) Serum 25-hyrdroxyvitamin D concentration and subsequent risk of type 2 diabetes. Diabetes Care 30, 2569-2570.

6. Maghbooli Z, Hossein-Nezhad A, Karimi F, et al. (2008) Correlation between vitamin $\mathrm{D}_{3}$ deficiency and insulin resistance in pregnancy. Diabetes Metab Res Rev 24, 27-32.

7. Alemzadeha R, Kichlerb J, Babara G, et al. (2008) Hypovitaminosis $\mathrm{D}$ in obese children and adolescents: relationship with adiposity, insulin sensitivity, ethnicity, and season. Metabolism 57, 183-191.

8. Forouhi NG, Luan Ja, Cooper A, et al. (2008) Baseline serum 25-hydroxy vitamin $\mathrm{D}$ is predictive of future glycemic status and insulin resistance: The Medical Research Council Ely Prospective Study 1990-2000. Diabetes 57, 2619-2626.

9. Kumar S, Davies M \& Zakaria Y (1994) Improvement in glucose tolerance and beta-cell function in a patient with vitamin $\mathrm{D}$ deficiency during treatment with vitamin D. Postgrad Med J 70, 440-443.

10. Borissova A, Tankova T, Kirilov G, et al. (2003) The effect of vitamin $\mathrm{D}_{3}$ on insulin secretion and peripheral insulin sensitivity in type 2 diabetic patients. Int J Clin Pract 57, 258-261.

11. Gedik O \& Akalin S (1986) Effects of vitamin D deficiency and repletion on insulin and glucagon secretion in man. Diabetologia 29, 142-145.

12. Tai K, Need AG, Horowitz M, et al. (2008) Glucose tolerance and vitamin $\mathrm{D}$ : effects of treating vitamin D deficiency. Nutrition 24, 950-956.

13. Nagpal J, Pande JN \& Bhartia A (2009) A double-blind, randomized, placebo-controlled trial of the short-term effect of vitamin $\mathrm{D}_{3}$ supplementation on insulin sensitivity in apparently healthy, middle-aged, centrally obese men. Diabet Med 26, $19-27$.

14. Pittas AG, Lau J, Hu FB, et al. (2007) Review: the role of vitamin $\mathrm{D}$ and calcium in type 2 diabetes. A systematic review and meta-analysis. $J$ Clin Endocrinol Metab 92, 2017-2029.

15. Vieth R, Bischoff-Ferrari H, Boucher BJ, et al. (2007) The urgent need to recommend an intake of vitamin D that is effective. Am J Clin Nutr 85, 649-650.

16. Heaney RP, Davies KM, Chen TC, et al. (2003) Human serum 25-hydroxycholecalciferol response to extended oral dosing with cholecalciferol. Am J Clin Nutr 77, 204-210.

17. Vieth R, Chan P-CR \& MacFarlane GD (2001) Efficacy and safety of vitamin $D_{3}$ intake exceeding the lowest observed adverse effect level. Am J Clin Nutr 73, 288-294.

18. Ministry of Health, N.Z. (2006) Asian Health Chart Book 2006 Public Health Intelligence: Monitoring Report No. 4, p. 47. Wellington: Ministry of Health.

19. Von Hurst PR, Stonehouse W, Kruger MC, et al. (2007) Vitamin D status of South Asian women living in New Zealand (abstract). Asia Pac J Clin Nutr 16, S50.

20. Von Hurst PR, Stonehouse W, Matthys C, et al. (2008) Metabolic syndrome, vitamin D and bone status in South Asian women living in Auckland, New Zealand: a randomised, placebo-controlled, double-blind vitamin D intervention. BMC Public Health 8, 1-8.

21. Deepa R, Shanthirani SS, Premalatha G, et al. (2002) Prevalence of insulin resistance syndrome in a selected South Indian population - the Chennai urban population study-7 (CUPS-7). Indian J Med Res 115, 118-127.

22. Reaven GM (2005) The insulin resistance syndrome: definition and dietary approaches to treatment. Annu Rev Nutr 25, 391-406.

23. Matthews DR, Hosker JP, Rudenski AS, et al. (1985) Homeostasis model assessment: insulin resistance and beta-cell function from fasting plasma glucose and insulin concentrations in man. Diabetologia 28, 412-419.

24. Bonora E, Targher G, Alberiche M, et al. (2000) Homeostasis model assessment closely mirrors the glucose clamp technique in the assessment of insulin sensitivity. Diabetes Care 23, 57-63.

25. Wallace T, Levy J \& Matthews D (2004) Use and abuse of HOMA modelling. Diabetes Care 27, 1487-1495.

26. Levy JC, Matthews D \& Hermans M (1998) Correct homeostasis model assessment (HOMA) evaluation uses the computer program. Diabetes Care 21, 2191-2192.

27. Sari R, Balci MK, Balci N, et al. (2007) Acute effect of exercise on plasma leptin level and insulin resistance in obese women with stable caloric intake. Endocr Res 32, 9-17. 
28. Medsafe New Zealand (2006) Medicine Data Sheets. http:// www.medsafe.govt.nz/profs/Datasheet/SearchResult.asp (accessed 16 April 2009).

29. Chel V, Ooms M \& Popp-Snijders C (1998) Ultraviolet irradiation corrects vitamin $\mathrm{D}$ deficiency and suppresses secondary hyperparathyroidism in the elderly. $J$ Bone Miner Res 13, 1238-1242.

30. Taylor A \& Wise P (1998) Vitamin D replacement in Asians with diabetes may increase insulin resistance. Postgrad Med $J$ 74, 365-366.

31. Barger-Lux MJ, Heaney RP, Dowell S, et al. (1998) Vitamin D and its major metabolites: serum levels after graded oral dosing in healthy men. Osteoporos Int 8, 222.

32. Jones G, Strugnell SA \& Deluca HF (1998) Current understanding of the molecular actions of vitamin D. Physiol Rev 78, 1193-1231.

33. Cade C \& Norman AW (1986) Vitamin $D_{3}$ improves impaired glucose tolerance and insulin secretion in the vitamin D-deficient rat in vivo. Endocrinology 119, 84-90.

34. Chertow BS, Sivitz WI, Baranestsky NG, et al. (1983) Cellular mechanisms of insulin release: the effects of vitamin D deficiency and repletion on rat insulin secretion. Endocrinology 113, 1511-1518.

35. Johnson J, Grande J, Roche P, et al. (1994) Immunohistochemical localization of the $1,25(\mathrm{OH}) 2 \mathrm{D}_{3}$ receptor and calbindin D28k in human and rat pancreas. J Clin Endocrinol Metab 267, E356-E360.

36. Chiu KC, Chu A, Go VLW, et al. (2004) Hypovitaminosis D is associated with insulin resistance and beta cell dysfunction. Am J Clin Nutr 79, 820-825.

37. Weisberg S, McCann D, Desai M, et al. (2003) Obesity is associated with macrophage accumulation in adipose tissue. J Clin Invest 112, 1796-1808.

38. Kershaw EE \& Flier JS (2004) Adipose tissue as an endocrine organ. J Clin Endocrinol Metab 89, 2548-2556.
39. Schleithoff SS, Zittermann A, Tenderich G, et al. (2006) Vitamin D supplementation improves cytokine profiles in patients with congestive heart failure: a double-blind, randomized, placebo-controlled trial. Am J Clin Nutr 83, 754-759.

40. Muller K, Haahr P, Diamant M, et al. (1992) 1,25-dihydroxyvitamin $\mathrm{D}_{3}$ inhibits cytokine production by human blood monocytes at the post-transcriptional level. Cytokine 4, 506-512.

41. Canning M, Grotenhuis K, Wit Hd, et al. (2001) 1-Alpha, 25-dihydroxyvitamin $\mathrm{D}_{3}$ hampers the maturation of fully active immature dendritic cells from monocytes. Eur J Endocrinol 145, 351-357.

42. Timms PM, Mannan N, Hitman GA, et al. (2002) Circulating MMP9, vitamin D and variation in the TIMP-1 response with VDR genotype: mechanisms for inflammatory damage in chronic disorders? QJM 95, 787-796.

43. Kelley-Hedgepeth A, Lloyd-Jones DM, Colvin A, et al. (2008) Ethnic differences in C-reactive protein concentrations. Clin Chem 54, 1027-1037.

44. Maestro B, Davila N, Carranza MC, et al. (2003) Identification of a vitamin D response element in the human insulin receptor gene promoter. J Steroid Biochem Mol Biol 84, 223-230.

45. Maestro B, Campion J, Davila N, et al. (2000) Stimulation by 1,25-dihydroxyvitamin $\mathrm{D}_{3}$ of insulin receptor expression and insulin responsiveness for glucose transport in U-937 human promonocytic cells. Endocr J 47, 383-391.

46. Maestro B, Molero S, Bajo S, et al. (2002) Transcriptional activation of the human insulin receptor gene by 1,25-dihydroxyvitamin $\mathrm{D}_{3}$. Cell Biochem Funct 20, 227-232.

47. Withers D \& White M (2000) Perspective: The insulin signaling system - a common link in the pathogenesis of type 2 diabetes. Endocrinology 141, 1917-1921.

48. Kim Y, Kotani K, Ciaraldi T, et al. (2003) Insulin-stimulated protein kinase $\mathrm{C}$ lambda/zeta activity is reduced in skeletal muscle of humans with obesity and type 2 diabetes. Diabetes 52, 1935-1942. 